\title{
Impact of population dynamics of white mistletoe (Viscum album ssp. abietis) on European silver fir (Abies alba)
}

\author{
Konrad Philipp NOETZli*, Beat MÜLlER, Thomas Niklaus SIEBER \\ Swiss Federal Institute of Technology, Department of Forest Sciences, Section Forest Pathology \& Dendrology, \\ ETH Zentrum, Rämistrasse 101, 8092 Zürich, Switzerland
}

(Received 21 January 2002; accepted 20 September 2002)

\begin{abstract}
In a 70-yr-old stand of European silver fir (Abies alba) in the Rhine Valley (Canton of Grisons, Switzerland), 27 trees with heavy infestation of white mistletoe (Viscum album ssp. abietis) were felled and population dynamics of the parasite as well as the growth patterns of the host trees were analysed. The growth curves of these trees were compared with those of 10 uninfested trees in the same stand to find temporal correlations between growth trends and the disease progress. Before 1983, incidence of mistletoe was insignificant but increased drastically thereafter. The growth patterns of the infested and the uninfested trees did not differ significantly before the epidemic began. During the exponential growth of the mistletoe population, growth increment of the infested trees decreased continuously whereas growth of the control trees remained regular. It can be concluded that a high degree of mistletoe attack has a negative effect on growth of the host trees.
\end{abstract}

Viscum album / Abies alba / population dynamics / host physiology / growth performance

Résumé - Influence de la dynamique d'évolution de la population du gui (Viscum album ssp. Abietis) sur le sapin pectiné (Abies alba). Dans un peuplement de sapin pectiné (Abies alba) de 70 ans situé dans la vallée du Rhin (Canton des Grisons, Suisse), 27 arbres infestés par le gui (Viscum album ssp. abietis) ont été abattus. La croissance de ces arbres et la dynamique de la population du parasite ont été analysées. La courbe de croissance de ces arbres a été comparée avec celle de 10 arbres non-infestés dans le même peuplement afin d'étudier les corrélations entre les tendances d'accroissement et l'évolution de l'infection. La population du gui a augmenté de façon dramatique depuis 1983, année avant laquelle il était insignifiant. La croissance des arbres infestés et non-infestés était comparable avant le début de l'épidémie. Après, l'accroissement moyen des arbres infestés était en constant déclin tandis que l'accroissement des arbres témoins restait régulier. La conclusion est qu'une attaque massive de gui a un effet négatif sur la croissance des arbres infestés.

Viscum album / Abies alba / dynamique de population / physiologie de l'hôte / croissance

\section{INTRODUCTION}

The hemiparasitic white mistletoe Viscum album L. attacks many species of deciduous trees. In addition, some coniferous species are affected, notably European silver fir (Abies alba Mill.) and Scots pine (Pinus sylvestris L.) by V. album ssp. abietis (Wiesb.) Abromeit and V. album ssp. austriacum (Wiesb.) Vollmann, respectively [10]. The sinkers of the parasite and the succeeding invasion of microorganisms - such as fungi or bacteria - cause mechanical and aesthetic damages of the wood and reduce its commercial value $[11,12,29]$.

In Switzerland, particularly in the Cantons of Valais and Grisons, local forestry observed the parasite to invade new territories, to reach alarming intensity and consequently to affect growth performance and health of infected trees [9, 34]. Attempting to control the disease, local forestry is removing the infested trees, what is impeding the implementation of silvicultural concepts in heavily infested stands with Scots pine and European silver fir. Furthermore, it seems to be a trend of about 50 years old trees to be infested and even killed by the parasite [33].

While the effect on wood quality is obvious, the impact of the parasite on host physiology is discussed controversially. For other genera of mistletoes such as Arceuthobium sp., intense losses in vitality leading to death of the host trees are reported by several authors [6, 7, 23, 24, 27]. In early studies, Viscum album ssp. abietis was considered to be a parasite which causes big losses in wood production [21, 28] and which is even able to kill whole stands of Abies alba [3, 22, 25], while more recent studies suggested that only single trees can be killed when infestation is very heavy $[9,17,28]$.

\footnotetext{
* Corresponding author: konrad.noetzli@vd.zh.ch
} 
The impact of Viscum album ssp. abietis on Abies alba was examined in several studies $[13,15,16,31]$. In all these studies, the annual radial growth increment was used to quantify the growth behaviour of the host trees. Infested trees always showed a negative growth trend. Other authors described the population growth of white mistletoe on Pinus spp. to fluctuate $[5,32]$.

All of these studies were restricted to either one of the two main aspects of this disease: "growth of the host tree" or "growth of the parasite population". But the two parameters have never been examined together, so far. Demonstration of a temporal correlation between growth of the parasite population and growth of the host trees is necessary to confirm the hypothesis that Viscum album has a negative influence on growth of its host trees. It is, therefore, important to verify whether the growth of the host trees decreases before or during the infestation.

In the present study, temporal correlations between the population growth of Viscum album ssp. abietis and the annual increment of its host Abies alba were analysed. The main objective was to show whether infested and uninfested trees in the same stand show differences in their growth behaviour before and/or during the infestation. Furthermore, a rapid field method of age determination of mistletoes [32] was compared with a more reliable but more time consuming laboratory method [5].

\section{MATERIALS AND METHODS}

Twenty seven infested and 10 uninfested trees (in the following called control group) of Abies alba were selected and felled during winter season 1997/1998 in an approximately 70-yr-old stand near Domat/Ems (Canton of Grisons, Switzerland, grid reference 753.600/ 187.800, National Topographical Map of Switzerland). The study site of about 6.5 ha was situated on between 650 and $770 \mathrm{~m}$ above sea level.

Trees were selected according to the following criteria: Diameter at breast height $(\mathrm{DBH})$ between 20 and $30 \mathrm{~cm}$, living crown length at least one third of tree height, dominant or codominant (according to Kraft's classification of tree social positions [14]). Trees had to host at least ten big mistletoes (diam. $>30 \mathrm{~cm}$ ) visible from the ground to be considered as "infested". The trees of the control group - bearing no mistletoes visible from the ground - were examined after felling on mistletoe attack. Trees showing any infestation were excluded from the control group whereas mistletoes younger than 3 years were not taken into account.

A stem disk at breast height was taken from each tree after felling as well as another one from the base of the living crown. The former was used to approximate the age of the trees by counting the growth rings. The latter was used to study the growth behaviour of each tree. The radial growth pattern of such a disk may be less influenced by climatic and other external factors than a disk from the stem base [18]. Annual growth increment was measured on four representative radii of each stem disk using a tree-ring analysis machine (LINTAP, Frank Rinn Distribution, Heidelberg, Germany) and averaged to receive the growth curve of the tree. The number of growth rings and the diameter of the disks from breast height as well as from the base of the living crown were compared between the two groups in order to detect systematic differences between the two groups.

The population dynamics of the parasite were reconstructed by determining the age of each mistletoe on the infested trees. The term

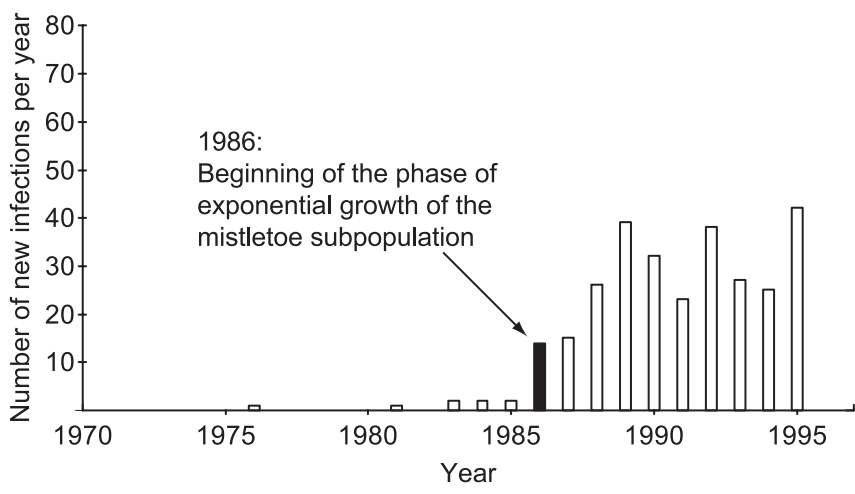

Figure 1. Example of a mistletoe population dynamic on a single infested tree (No. 14). The first year with more than 10 new mistletoes (black column) was defined as the beginning of the phase of exponential growth of the mistletoe subpopulation. Note that this point of time represents the individual "starting point" of disease on this tree.

"population" is used in the following to indicate the mistletoes on all infested trees whereas for the mistletoes on an individual tree the term "subpopulation" is used [1]. As the age of a living mistletoe represents directly the year of the infection [17, 32], the number of mistletoes having a certain age represents the disease increase in the corresponding year.

Two methods were applied to determine the age of the mistletoes. The first method (called "field method" hereafter), which is based on the regular dichotomous branching of the mistletoe, allows a rapid determination of the age by counting the shoot segments of the plant and was applied just after the tree was felled [28, 29, 32]. The second method ("laboratory method") was used when shoots of a mistletoe were ripped off during the tree was felled. The pieces of wood where the mistletoe penetrated the bark were excised from the branch or stem and brought to the laboratory. The tip of the primary sinker was uncovered by cutting the wood radially through the infection point and careful grinding the cut surface. It was then possible to count the number of growth rings of the host branch enclosing the primary sinker. This number corresponds with the number of years since the mistletoe established on the branch [5]. In the present study, mistletoes younger than 3 years (comprising the non-parasitic stadium during the first vegetation period) were not included due to a high risk of overseeing the tiny shoots of the parasite on the branches. Since the two methods have never been compared directly, the age of 129 mistletoes randomly selected from all except two infested trees (1 to 22 mistletoes per tree) was determined by both methods and the two results were analysed for systematic errors by regression analysis.

The cumulative population growth of the mistletoe was calculated by adding the subpopulations of the mistletoes from each tree. Among-tree variation of infestation in a particular year was displayed in box plots [30]. The growth patterns of all trees were analysed from 1970 to 1997. As the infested trees and the control group were taken from the same stand, differences between increment growth should not be biased by external factors such as climate and weather [2].

On each infested tree, the first year when 10 or more new infections occurred was used to distinguish between the time before the disease - including a latent period as an initial phase of the disease and a phase of exponential growth of the mistletoe subpopulations (Fig. 1). This point of time was chosen because a slight mistletoe attack generally does not affect tree growth [29] and because once 10 or more new infections occurred in a year, only on a few trees infection rate dropped bellow this limit thereafter. Thus, the period of time 


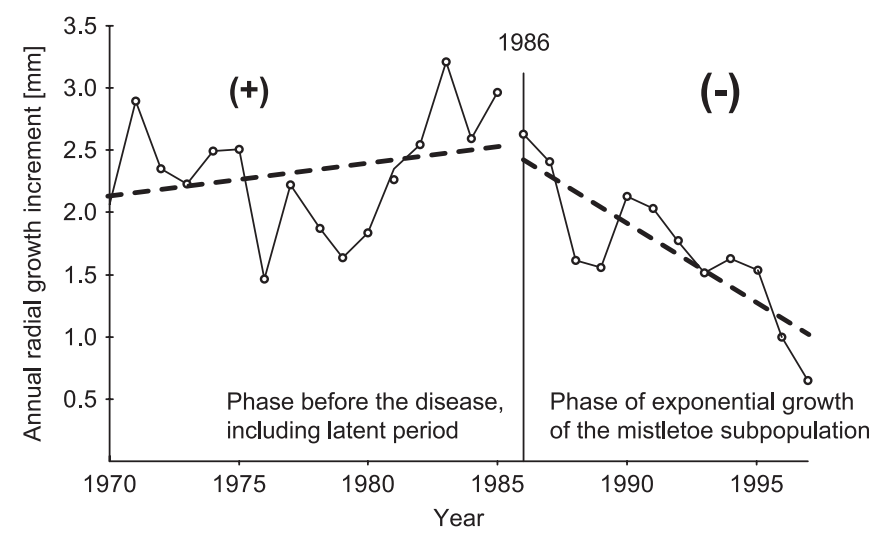

Figure 2. Example for the determination of the growth trend of an infested tree (No. 14). After splitting the growth curve at the point of time, where the mistletoe subpopulation began to grow exponentially (1986) the trends were calculated separately for the two periods by linear regression (---: regression lines). This tree showed a positive trend $(+)$ before and a negative trend $(-)$ during the infestation.

considered in this study was divided into two time intervals "before" and "during" infestation, individually for each tree. As there are no such time intervals for the trees of the control group, the average beginning of the phase of exponential growth of the mistletoe subpopulations on the infested trees (1988) was used to define two analogue time intervals.

The growth trend of each infested tree was analysed separately for the time before and during the infestation by linear regression (Fig. 2). If the gradient of the regression line was significantly negative $(\beta<0, P \leq 0.05)$ the trend was classified as "negative". In all other cases (gradient not significant or positive), the trend was classified as "positive". Subsequently, the ratio of trees with a negative trend was calculated for the two time intervals. Tree No. 12 (beginning of the phase of growth of the mistletoe subpopulation in 1995) was excluded from this analysis, because the period "during" the infestation was represented by only two values. The ratio of negative trends in the control group before and after 1988 was used as a reference for the growth behaviour of healthy trees under the same conditions. The ratios were compared for the periods before and during infestation ( $<1988$ and $\geq 1988$ respectively) by using contingency tables $(2 \times 2)$ and Fisher's exact test.

\section{RESULTS}

The two methods of age determination of the mistletoes were compared by plotting the age determined by the field method against the age determined by the laboratory method for each plant. Field-determined and laboratory-determined age were closely correlated (linear regression, $\mathrm{R}^{2}=0.86$ ) (Fig. 3). The slight deviation of the regression line from the straight line with the equation $\mathrm{x}=\mathrm{y}$, which would indicate identical results for both methods, was statistically significant $(P<0.05)$. Considering the age determined by the laboratory method as the true age of a mistletoe, young mistletoes were systematically underestimated by the field method whereas old mistletoes were overestimated. However, within the range of ages found, the estimation error did not exceed one year. Thus, the age determined by the field method remained a good estimation of the age determined in the laboratory.

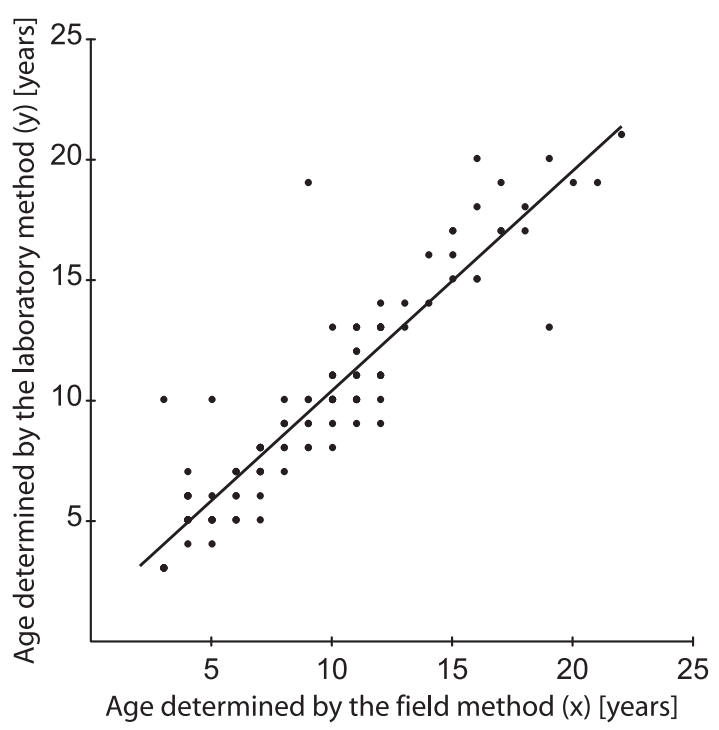

Figure 3. Scatterplot showing the mistletoe age determined by the field versus the laboratory method. The following equation applies for the regression line: $y=0.9125 x+1.263 ; R^{2}=0.86$. Each dot represents one individual mistletoe $(\mathrm{N}=129)$. Some dots in the graph are superposed due to identical values.

A total of 6830 mistletoes were collected from the infested trees. The age of 167 individuals $(2.4 \%)$ could not be determined because they either were dead or the tip of their primary sinker could not be found. The remaining 6663 mistletoe were used for further analysis (Tab. I). The oldest dateable mistletoe had an age of 23 years.

Regarding the diameters of the disks taken at breast height and at the base of the living crown, no significant differences were found between the infested and the uninfested trees ( $t$-test, $P>0.05)$. Whereas the number of growth rings of the stem disks at the base of the living crown did not differ between the two groups, there was a significant difference of about 12 rings in the disks taken at breast height $(t$-test, $P<0.05)$.

The cumulative disease progress curve showed a nearly exponential trend (Fig. 4a). The among tree-variation of mistletoe infestation was high, but the exponential increase in the eighties and nineties was distinct for all trees (Fig. 4b). Comparing the growth of infested and uninfested trees there was a slightly lower increment in the group of the infested trees (Fig. 5). However, from 1970 to 1989 , the two groups did not differ significantly, whereas there was a significant difference from 1990 onwards ( $t$-test, two-sided, $P \leq 0.05$ ). The difference between the two groups started to increase in 1986, following a negative linear trend $(P \leq 0.05)$ until the end of the observation period in 1997.

In the group of the infested trees there was a ratio of negative to positive increment trends of $9 / 17$ before the infestation which changed to $16 / 10$ during the phase of exponential growth of the mistletoe subpopulations. The analogue ratios for the control group were 3/7 and 0/10 (Tab. II). Changing the reference year 1988 for the trees of the control group by \pm 4 years did not influence these ratios. While the contingency table test did not show any differences between the two groups before 
Table I. Data collected from the studied trees. The number of growth rings at breast height approximates the age of each tree. The size of mistletoe subpopulations on the infested trees in 1997 and the beginning of infestation (first year with more than 10 new infections) is given. Only living mistletoes older than 3 years were recorded. Underlined figures indicate the biggest and the smallest population.

\begin{tabular}{|c|c|c|c|c|c|c|}
\hline \multirow[b]{2}{*}{ Tree No. } & \multicolumn{2}{|c|}{ Breast height } & \multicolumn{2}{|c|}{ Base of the living crown } & \multirow{2}{*}{$\begin{array}{l}\text { Number of mistletoes } \\
\text { in } 1997\end{array}$} & \multirow{2}{*}{$\begin{array}{l}\text { Beginning } \\
\text { of infestation }\end{array}$} \\
\hline & Diam. $[\mathrm{cm}]$ & Growth rings & Diam. $[\mathrm{cm}]$ & Growth rings & & \\
\hline \multicolumn{7}{|c|}{ Infested trees } \\
\hline 1 & 26 & 120 & 22 & 44 & 274 & 1987 \\
\hline 2 & 26 & 71 & 17 & 30 & 230 & 1985 \\
\hline 3 & 20 & 89 & 14 & 38 & 160 & 1990 \\
\hline 4 & 29 & 64 & 18 & 32 & 164 & 1988 \\
\hline 5 & 27 & 70 & 17 & 31 & 195 & 1986 \\
\hline 6 & 27 & 61 & 21 & 44 & 158 & 1987 \\
\hline 7 & 30 & 79 & 23 & 44 & $\underline{652}$ & 1984 \\
\hline 8 & 23 & 58 & 15 & 39 & 215 & 1987 \\
\hline 9 & 20 & 56 & 13 & 34 & 105 & 1987 \\
\hline 10 & 26 & 93 & 20 & 38 & 245 & 1987 \\
\hline 11 & 30 & 55 & 20 & 32 & 648 & 1983 \\
\hline 12 & 23 & 69 & 14 & 35 & $\underline{79}$ & 1995 \\
\hline 13 & 25 & 61 & 18 & 23 & 147 & 1990 \\
\hline 14 & 24 & 71 & 17 & 38 & 289 & 1986 \\
\hline 15 & 25 & 85 & 16 & 44 & 312 & 1987 \\
\hline 16 & 24 & 81 & 17 & 41 & 313 & 1988 \\
\hline 17 & 25 & 77 & 14 & 30 & 108 & 1989 \\
\hline 18 & 25 & 67 & 18 & 28 & 198 & 1990 \\
\hline 19 & 24 & 54 & 16 & 26 & 224 & 1990 \\
\hline 20 & 23 & 55 & 16 & 28 & 95 & 1990 \\
\hline 21 & 24 & 69 & 17 & 37 & 446 & 1989 \\
\hline 22 & 21 & 58 & 12 & 22 & 98 & 1992 \\
\hline 23 & 27 & 62 & 17 & 32 & 314 & 1990 \\
\hline 24 & 23 & 67 & 16 & 37 & 351 & 1985 \\
\hline 25 & 25 & 54 & 16 & 29 & 140 & 1992 \\
\hline 26 & 24 & 62 & 16 & 29 & 154 & 1987 \\
\hline 27 & 24 & 69 & 14 & 32 & 349 & 1987 \\
\hline Average & 24.8 & 70 & 16.8 & 34.0 & 246 & 1988 \\
\hline \multicolumn{7}{|c|}{ Control group } \\
\hline 1 & 23 & 59 & 17 & 32 & Uninfested $^{1}$ & \\
\hline 2 & 27 & 56 & 21 & 30 & Uninfested & \\
\hline 3 & 26 & 58 & 17 & 24 & Slightly infested ${ }^{2}$ & \\
\hline 4 & 22 & 62 & 15 & 32 & Uninfested & \\
\hline 5 & 25 & 52 & 20 & 34 & Uninfested & \\
\hline 6 & 26 & 66 & 16 & 30 & Uninfested & \\
\hline 7 & 24 & 65 & 15 & 26 & Uninfested & \\
\hline 8 & 21 & 66 & 13 & 28 & Uninfested & \\
\hline 9 & 28 & 46 & 19 & 32 & Uninfested & \\
\hline 10 & 27 & 47 & 21 & 29 & Uninfested & \\
\hline Average & 24.9 & 58 & 17.4 & 29.7 & & \\
\hline
\end{tabular}

${ }^{1}$ Only mistletoes younger than 3 years considered. ${ }^{2}$ Three mistletoes (diam. $<30 \mathrm{~cm}$ ) detected. 
a)

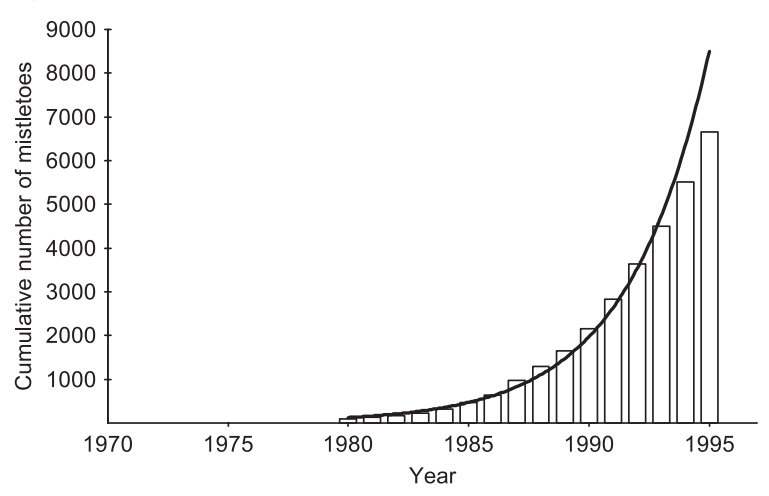

b)

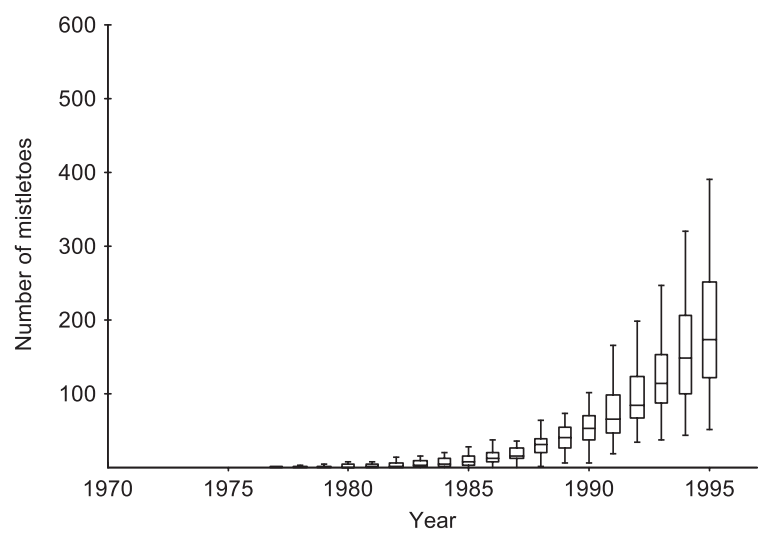

Figure 4. Mistletoe population dynamic: (a) Cumulative growth of the mistletoe population on all infested trees (sums of the number of mistletoes on all infested trees). Equation of the regression line: $\mathrm{y}=$ $76.6 \mathrm{e}^{0.29(\mathrm{x})} ; \mathrm{x}=$ Year $-1979 ; \mathrm{y}=$ cumulative number of mistletoes; $\mathrm{R}^{2}=0.99$. (b) Growth of the mistletoe subpopulations on the infested trees. Each box-plot [30] represents the among-tree variation of the subpopulation size in a particular year.

the attack of the parasite, the number of trees with a negative growth trend was significantly higher in the group of infested trees during the infestation (Fisher's exact test, $P \leq 0.05$ ).

\section{DISCUSSION AND CONCLUSIONS}

The results gained by the two methods of age determination used in this study were highly correlated. The calculated error of \pm one year can be considered negligible, i.e. both methods give reliable results.

After the initial visual assessment from the ground, all of the infested trees were supposed to be heavily attacked and to host about the same number of mistletoes. The great among-treevariation observed after felling the trees (79 to 652 mistletoe on a single tree) shows the insufficiency of assessing intensity of mistletoe attack from the ground. This result corresponds with the findings of Vallauri for V. album ssp. austriacum [32].
Table II. Number of trees with negative and positive growth trends within the groups of infested and uninfested trees for contingency table analysis. Using the average year of the beginning of infestation on the infested trees (1988), the observation period for the control group was artificially divided into two time intervals which correspond to the time intervals "before" and "during" the infestation on the infested trees. This approach allowed a direct comparison between the two groups in analogue time intervals.

\begin{tabular}{lccc}
\hline Before infestation: & & $\begin{array}{c}\text { Infested } \\
\text { trees }\end{array}$ & $\begin{array}{c}\text { Control } \\
\text { group }\end{array}$ \\
\hline $\begin{array}{l}\text { Number of trees with decreasing growth } \\
\text { Number of trees with increasing or constant } \\
\text { growth }\end{array}$ & $(-)$ & 9 & 3 \\
& Total & 26 & 17 \\
\hline $\begin{array}{l}\text { During infestation: } \\
\text { Number of trees with decreasing growth }\end{array}$ & & $\begin{array}{c}\text { Infested } \\
\text { trees }\end{array}$ & $\begin{array}{c}\text { Control } \\
\text { group }\end{array}$ \\
$\begin{array}{l}\text { Number of trees with increasing or constant } \\
\text { growth }\end{array}$ & $(+)$ & 16 & 0 \\
& Total & 26 & 10 \\
\hline
\end{tabular}

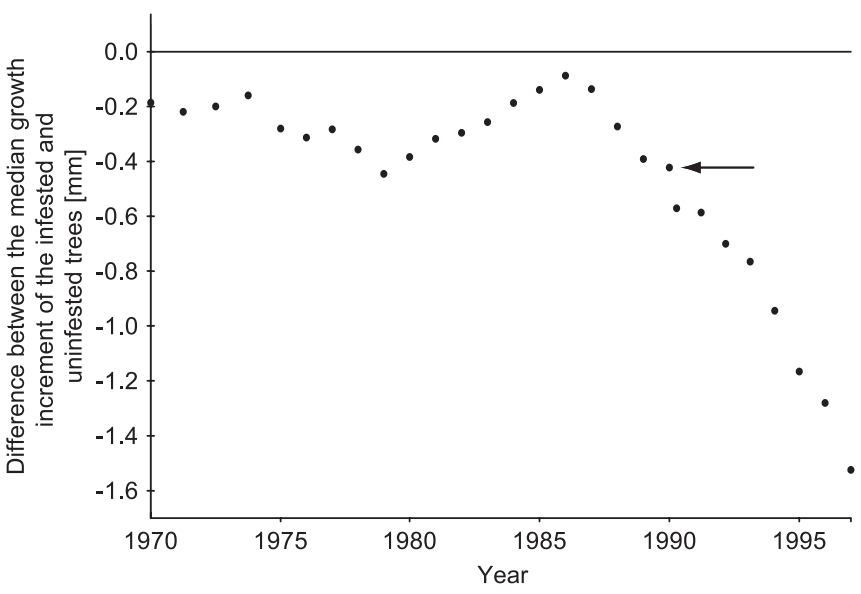

Figure 5. Differences between infested trees und the control group regarding the average growth increment. One dot represents the difference between the average increment of all infested trees $(\mathrm{N}=27)$ and the corresponding increment of the control group $(\mathrm{N}=10)$ in a particular year. Differences were significant from 1990 (arrow) onwards $(t$-test, $P<0.05)$.

In the studied stand, the population of white mistletoe increased since about 15 years, following a nearly exponential trend (Fig. 4). Disease increase is postulated to follow a logistic model in many host-parasite systems [8]. These epidemics are characterised by sigmoid disease progress curves with a lag, an exponential and a stall phase, i.e. with low population growth at the beginning and at the end of the epidemic and high growth rates during the exponential phase. Decreasing trends or fluctuations of the mistletoe population as observed by Vallauri [32] were not detected in our material. Thus, the 
mistletoe population was still in the exponential phase and had not reached its maximum growth rate in 1997 when the trees were felled.

Infested and uninfested trees did not show different increment trends before the start of the infestation. During the epidemic, average increment of the infested trees decreased. This result matches older studies of the same parasite-host combination $[16,32]$ but with the additional finding, that the growth increment started to decrease with a delay of 1 to 5 years in respect of the beginning of infestation.

In general, the radial growth trend of 70-yr-old silver firs is expected to increase or at least to remain constant [2] as it was found in the control group. The annual growth increment decreased, however, significantly in the group of infested trees. The fact that the two groups did not differ from each other before the infestation and during a possible latent period indicates that the mistletoes had a negative effect on infested trees once the mistletoe population started to increase exponentially. This is not in accordance with other reports [22], in which any adverse influence on growth of silver firs younger than 120 years was doubted. The present study did, however, not allow to find the mechanisms by which the mistletoes influence tree growth. Dehydration and depletion of nutrients [5] rather than toxic effects [4] are supposed to be the primary causes.

Despite the detected negative correlation between the size of the mistletoe subpopulation and the growth increment of host trees, it should not be neglected that wood increment is only one of many possible parameters to measure tree health. Other parameters such as leafmass, wood density, early- and latewood-width could be measured as well to improve the estimation of growth or health state [2]. Furthermore, the silvicultural treatment in the investigated stand between 1970 and 1997 might have biased the results, as changes of the light regime can cause short term changes in increment of a forest tree [26]. At last, it must be mentioned that the applied methods did not allow to draw conclusions about further disease progress.

To avoid economical losses due to mistletoe on silver fir, it was suggested to reduce the ratio of this tree species in favour of Norway spruce [28]. In view of the decreasing proportion of Abies alba in the subalpine forests in Switzerland, it is, however, not recommended to follow such a strategy for ecological reasons [19]. In addition, a correlation between the abundance and spatial distribution of host trees and the frequency of mistletoes has not been shown, yet. Previous studies with similar host-parasite combinations [20,32] did not show correlation between spatial density of hosts and parasites. Eliminating infested trees may not be suitable to control the disease as well, as in thinned stands, light conditions may improve the growth of mistletoes. Similarly, the living conditions in a thinned stand may be better for the mistle thrush (Turdus viscivorus L.), the main vector of the parasite $[22,28,29]$. This bird species probably plays an important role in the population dynamics of white mistletoe. Nevertheless, there are not many studies dealing with this aspect of the disease and further research is needed.

Returning to the main question of the impact of white mistletoe on its host, it has been shown in a representative stand of silver fir, that the growth increment of trees - both average and individual - began to decrease after the number of mistletoes began to increase exponentially. It can be concluded that the parasite is likely to have a negative influence on its host when the mistletoe population reaches a critical size. The results of this study do, however, not allow to decide, whether the damaging influence of white mistletoe would lead to an increased mortality of the infested tree. Long-term monitoring studies in well-known stands with controlled forest management will be the only instrument to answer this question.

Acknowledgements: The authors wish to thank the local forestry staff of Domat/Ems (GR), in particular Mr. L. Koch and Mr. M. Rageth for providing the study plot and all necessary infrastructure for field work and Dr. R. Zuber from the Forstinspektorat Chur (GR) for inspiring discussions. Furthermore we wish to thank Mr. O. Schärer, Hirzel (ZH), for providing the equipments for the laboratory works, Prof. Dr. F.H. Schweingruber and Mr. P. Nogler from the Swiss Federal Research Institute WSL, Birmensdorf $(\mathrm{ZH})$, for support in the tree ring analysis and Prof. Dr. O. Holdenrieder, Swiss Federal Institute of Technology Zürich, Department of Forest Sciences, for scientific support and many discussions about the subject.

\section{REFERENCES}

[1] Begon M., Harper J.L., Townsend C.R., Ecology: individuals, populations and communities, Blackwell Science, Oxford etc., 1999.

[2] Bräker O.U., Der Alterstrend bei Jahrringdichten und Jahrringbreiten von Nadelhölzern und sein Ausgleich, Mitt. Forstl. BundesVers. anst. Wien 142 (1981) 74-102.

[3] Coaz J., Über die Verbreitung der Mistel (Viscum album L.) in der Schweiz, Naturw. Z. Forstwes. Landw. 16 (1918) 138-195.

[4] Gäumann E., Pflanzliche Infektionslehre, Birkhäuser, Basel, 1951.

[5] Hartmann T., Anatomische und morphologische Untersuchungen zum Wechselverhältnis von Mistelpflanzen und ihren Wirtspflanzen am Beispiel der Tannenmistel und der Kiefernmistel, Master Thesis Techn. University Berlin, 1994.

[6] Hawksworth F.G., Dwarf Mistletoes: Biology, Pathology and Systematics, United States Department of Agriculture, Washington, DC. 1996.

[7] Hawksworth F.G., Geils B.W., How long do mistletoe-infected ponderosa pine live? West. J. Appl. For. 5 (1989) 47-48.

[8] Heinrich D., Hergt M., Atlas de l'écologie, Librairie Générale Française, Paris 1993.

[9] Hofstetter M., Über die Verbreitung der Mistel in der Schweiz. Schweiz. Z. Forstwes. 139 (1988) 81-95.

[10] Janssen T., Wulf A., Zur Bedeutung von Misteln im Forstschutz, Parey, Berlin, 1999.

[11] Knuchel H., Die Holzfehler, Classen, Zürich, 1947.

[12] König E., Die Fehler des Holzes, Holz-Zent.bl. 83 (1957) 222-234.

[13] Kontic R., Niederer M., Nippel C.-A., Winkler-Seifert A., Jahrringanalysen an Nadelbäumen zur Darstellung und Interpretation von Waldschäden (Wallis, Schweiz), Ber. Eidgenöss. Anst. Forstl. Vers.wes. 283 (1986).

[14] Kramer H., Akça A., Leitfaden für Dendrometrie und Bestandesinventur, Sauerländer, Frankfurt a. M., 1987.

[15] Lange K., Jahrringanalytische Untersuchungen an Weisstannen (Abies alba Mill.) im Churer Rheintal mit besonderer Berücksichtigung der Mistel (Viscum album L.), unpub. Dipl. Thesis Institute of Systematic Botany, Univ. Zürich, 1986.

[16] Nanu N., Viscum album L., a parasite in Abies alba stands on the calcareous Anina-Oravita plateau, Rev. Padur. 84 (1969) 177-178. 
[17] Nierhaus-Wunderwald D., Lawrenz P., Zur Biologie der Mistel, Merkbl. Prax. Eidgenöss. Forsch.anst. Wald Schnee Landsch. 28 (1997).

[18] Nogler P., Auskeilende und fehlende Jahrringe in absterbenden Tannen (Abies alba Mill.), Allg. Forstz. 28 (1981) 9-11.

[19] Ott E., Frehner M., Frey H.U., Lüscher P., Gebirgsnadelwälder: Ein praxisorientierter Leitfaden für eine standortgerechte Waldbehandlung, Haupt, Bern etc., 1997.

[20] Overton J.M., Spatial autocorrelation and dispersal in mistletoes: Field and simulation results, Vegetatio 125 (1996) 83-98.

[21] Péter-Contesse J., Influence du gui sur la production du bois de service, J. For. Suisse 88 (1937) 145-153.

[22] Plagnat F., Le gui du sapin, Ann. Ec. Natl. Eaux For. 12 (1950) $157-231$.

[23] Scharpf R.F., Dwarf mistletoe on True Firs in California, Forest Pest Leaflet 89 (1964).

[24] Scharpf R.F., Hawksworth, F.G., Dwarf Mistletoe on Sugar Pine, Foerst Pest Leaflet 113 (1968).

[25] Schilling K., Mistel, Wald und Misteldrossel, Allg. Forst- Jagdztg. 58 (1882) 8-13.
[26] Schweingruber F.H., Tree Rings and Environment in Dendroecology, Haupt, Bern etc., 1996.

[27] Singh P., Carew G.C., Impact of eastern dwarf mistletoe in black spruce forests of Newfoundland, Eur. J. For. Path. 19 (1989) 305322.

[28] Stopp F., Unsere Misteln, A. Ziemsen, Wittenberg, 1961.

[29] Tubeuf K., Monographie der Mistel, Oldenburg, München and Berlin, 1923.

[30] Tukey J.W., Exploratory data analysis, Addison-Wesley, Reading Massachusetts etc., 1977.

[31] Uscuplic M., Influence of forest management on the occurence of silver fir mistletoe (Viscum album L.), Glasnik Sumarskog Fakulteta, Univerzitet u Beogradu 74 (1992) 7-18.

[32] Vallauri D., Dynamique parasitaire de Viscum album L. sur pin noir dans le bassin versant du Saignon (Préalpes françaises du sud), Ann. Sci. For. 55 (1998) 823-835.

[33] Zuber R., Forstschutz, Bündnerwald Beih. 12 (1983) 115-119.

[34] Zuber R., Mistelbefall im Bündner Rheintal: Bericht zur Kartierung und waldbauliche Empfehlungen, unpub. Rep. Forstinspektorat Chur, 1995. 